\title{
Swimming upstream: community economies for a different coastal rural development in Sweden
}

\author{
Milena Arias Schreiber ${ }^{1} \mathbb{C} \cdot$ Ida Wingren $^{2} \cdot$ Sebastian Linke $^{1}$
}

Received: 7 April 2019 / Accepted: 4 December 2019 / Published online: 23 December 2019

(c) The Author(s) 2019

\begin{abstract}
The EU Blue Growth agenda is being implemented at a time when European coastal fisheries and traditional fishing communities are struggling to survive or have already vanished from areas where they used to flourish. Driven by the strong conviction that current disadvantaged and vulnerable coastal fishers still have a central role to play in rural development, local level initiatives are calling for a different future for this fishery sector. The participants in these initiatives insist that coastal fisheries should not be driven to extinction, despite their low economic profitability and thus minimal contribution to economic growth compared to large-scale enterprises. Through participatory observation and informal interviews, we investigate one of these local level initiatives on the Swedish Baltic Sea coast and analyse how it aligns with a community economies' project based on a different economic perspective. We describe first the primary activities carried out by the initiative and follow by an examination on what drove it, how it has been maintained, and how it might spread. We conclude on the potentials of the community economies framework and project to advance a Blue degrowth agenda based on difference and not necessarily less.
\end{abstract}

Keywords Coastal small-scale fisheries $\cdot$ Degrowth $\cdot$ Community economies $\cdot$ Diverse economies $\cdot$ Baltic Sea $\cdot$ Grassroots initiative

\section{Introduction}

The sustainability of European fisheries has been increasingly discussed since the adoption of the European Union's Blue Growth agenda in 2012 (EC 2012). Questions about whether and how economic growth and sustainability can be achieved simultaneously in a resource-limited ocean have sparked new debates about demands for growth or degrowth (Eikeset et al. 2018; Hadjimichael 2018). In fisheries, two further areas of concern related to this growth/degrowth agenda are pertinent. The first deals with the efficacy of the

Handled by Osamu Saito, Institute of Sustainability and Peace, Japan.

Milena Arias Schreiber

milena.schreiber@gu.se

1 School of Global Studies, University of Gothenburg, Gothenburg, Sweden

2 Department of Service Management and Service Studies, Lund University, Lund, Sweden persevering European Union's top-down policy-setting (Eliasen et al. 2015), of which the Blue Growth Agenda is a case in point. The second, as Jentoft (2019) argues, is the bulk of evidence showing that ocean policies can exacerbate social inequalities and ecological deterioration, if they focus solely on economic growth and disregard distributional effects. Both concerns are relevant for current users of European seas, including coastal and industrial fishers who stand to profit or lose out from a policy that depicts the oceans as the new frontier for sustainable economic development.

The Blue Growth agenda is being implemented at a time when EU small-scale fisheries ${ }^{1}$ and traditional coastal fishing communities are struggling to survive or have already vanished from areas where they used to flourish (Arias Schreiber et al. 2018; Lloret et al. 2018). In the recent past, if not today, such fisheries provided high-quality seafood and local employment, and drove economic and social life in many rural areas (e.g., Menzies 2011; Snyder and St. Martin 2015). Yet over recent decades, EU coastal fisheries have

1 We use small-scale fisheries and coastal fisheries as synonyms throughout the remainder of the text. 
been neglected and marginalized relative to demands from large-scale commercial fisheries and pro-environmental organizations (Arias Schreiber et al. 2017; Said et al. 2016; Høst 2015; Ertör-Akyazı, this issue; Said and MacMillan, this issue). Moreover, an ongoing and in cases irreversible degradation of European marine ecosystems, the results of overfishing, and more recently climate change, have also been negatively impacting on coastal fishers and their communities (Lloret et al. 2018; Gascuel et al. 2016). Coastal fishing communities are, therefore, well known to be vulnerable and disadvantaged, in Europe and elsewhere (Jentoft 2019; Said and MacMillan, this issue).

The Swedish welfare state is no exception and most coastal fishers have been pushed out of their traditional occupations, largely as a consequence of reduced fish stocks and unfavourable top-down fishing policies (Arias Schreiber et al. 2018, 2017). At both international (EU) and national (Sweden) levels, policies have consistently favoured the employment of neoliberal-oriented fisheries' management tools. The stated aim of these tools is to maintain fish stocks at healthy levels ${ }^{2}$ while maximizing profits and economic efficiency, with the latter being a direct proxy for human welfare (see e.g. Prellezo et al. 2012; Symes and Phillipson 2009). However, these policies primarily benefit large, mobile fisheries that rely on economies of scale to achieve profitability. They bring no benefits to near-shore coastal fishers who lack financial capital, and for whom large investments are either too risky or simply beyond their reach (Høst 2015; Boonstra and Hentati-Sundberg 2016). Consequently, the majority of small-scale Swedish fishers have already vanished from the coastline (Krogseng 2016; Björvick 2013) and those remaining are struggling to survive the neoliberal regime of commodification and privatization of the ocean's commons (Arias Schreiber et al. 2018).

This article draws on the concepts of diverse economies and community economies to analyse a Swedish municipal initiative that attempts to prevent the imminent disappearance of coastal fisheries because of their low potential for economic growth in the face of the EU Blue Growth agenda, the Swedish neoliberal-oriented fisheries policies and the deteriorated status of the Baltic Sea ecosystem. The initiative is driven by the strong conviction that coastal fishing still has a central role to play in rural development and that its current disadvantaged and vulnerable status can and should be reversed. In an enterprise in line with a Blue degrowth perspective, the initiative's activities are directed to ensure a future for the coastal fishing sector, despite its low economic

\footnotetext{
2 These "healthy levels" are inscribed in the EU's Common Fishery Policy management objective of Maximum Sustainable Yield (MSY). See https://www.europarl.europa.eu/ftu/pdf/en/FTU_3.3.1.pdf. Arguably, the notion of MSY facilitates a neoliberal capitalist model with an emphasis on maximum profits and growth.
}

profitability and insignificant contribution to Swedish national economy in comparison to large-scale industrial fisheries (see STECF 2018). In other words, participants in the Simrishamn initiative oppose the cornucopian approach ${ }^{3}$ of the Blue Growth strategy, and propose an agenda that focuses on the contradiction between sustainability and endless economic growth as emphasized by the Blue degrowth paradigm (Hadjimichael 2018). Thus, the initiative aims at a more equitable system for limiting the access to fishing resources-one that does not favour this access to the most economically efficient-and a reduction in fisheries landings that will simultaneously foster the wellbeing of coastal communities and respect for the marine environment. Their activities to achieve these goals can be considered as local efforts towards a project for sustainable degrowth defined in one of its classical versions as "an equitable downscaling of production and consumption that increases human wellbeing and enhances ecological conditions at the local and global level, in the short and long term" (Schneider et al. 2010). Thus, this local initiative claims for a deep transformation where the focus is on "difference and not only less" (Kallis et al. 2014, 33) including different ways to decide which fisheries sectors ought to be developed and to pursue "different relations with the non-human world" (Kallis et al. 2014, 4).

As in claims for a degrowth society where everything is different (Kallis et al. 2014), a claim of difference aligns with theoretical concepts that emphasize the transformative potential of challenging the hegemonic framing of the economy as singularly capitalist. The term diverse economies (Gibson-Graham 2008) was coined and developed to embrace the vast number of different types of economic transactions, labour products, property, financial practices and enterprises that are not captured by a singular capitalist economy but, taken together, probably account for more assign value and almost certainly more of living well ${ }^{4}$ than mainstream capitalocentric economic activities (ibid.; Gibson-Graham et al. 2013). Examples of diverse economic practices are unpaid age and health care (with an estimated annual monetary value in the USA of US $\$ 200$ billion), solidarity cooperatives, voluntary work for non-profit organizations, charity shops, or loans among family members (Gibson-Graham et al. 2013). More recent examples are the hundreds of Community Supported Agriculture initiatives-and lately also Community Supported Fisheries initiatives - that have proliferated worldwide especially since the 2000s, which promote partnerships between farmers

\footnotetext{
${ }^{3}$ Cornucopian is used to describe the bold assumption that technological innovation and scientific knowledge and its application will guarantee the delivery of sustainable quantities of material goods and services for the present and future generations (Barry 2016).

${ }^{4}$ For an explanation of the term living well please read Ertör and Hadjimichael, this issue.
} 
and consumers, connecting consumers to the environment that provides their food and placing farmers' ways of life at the centre of economic transactions (Gibson-Graham et al. 2013). Under what has been termed a community economies approach, equal consideration is given to how these diverse economies enable individuals and households to survive, and to how they impact other people's lives and the environment (Gibson-Graham et al. 2013). The concept of a community economy challenges the description of wage labour, commodity production and for-profit capitalist enterprises as the real economy (Gibson-Graham et al. 2017). Instead, the economy is a "space of decision making where we recognize and negotiate our interdependence with other humans, other species, and our environment" (Gibson-Graham et al. 2013, 12).

Our analysis of one local initiative aiming for a different future for the Swedish coastal fisheries offers an empirical application of the community economies theoretical concepts, displaying their dynamics and exploring their potential for sustainable Blue degrowth. We investigate, therefore, the conditions for the emergence of a community economy based on a different economic perspective, examining what drove the initiative, what have been its primary activities, how it has been maintained, and how it might spread. We begin by describing the initiative, and then scrutinize more closely three of its key ongoing activities: the revitalization of local markets for fish, the access to local marine resources, and the representation and participation of coastal fishers in the political system, showing how these areas of activity work to reframe the local economy around ethical commitments. We conclude by reflecting on the potential of community economies for creating a different sustainable rural development which aligns with claims for a Blue degrowth.

\section{Different futures for Swedish coastal development}

\section{The Simrishamn initiative}

The municipality of Simrishamn, with a permanent population of about 20,000, is situated in the county of Skåne on the southern coastline of east Sweden (Simrishamn Municipality 2019). This part of rural Skåne is referred in Sweden as Österlen, and is popular among artists and wealthy urbanites who buy summer houses along the coastline for sometimes exorbitant prices (Gustavsson 2018). Simrishamn has had a tradition of fishing for centuries and was nicknamed "herring town." Coastal fishing and seafood processing were important occupations along the Baltic coast, and for decades Simrishamn was one of the largest Swedish fishing harbours in terms of the value of landed fish. Fisheries had great socio-cultural importance for Simrishamn's coastal communities, as living harbours that served as attractive meeting places for inhabitants and visitors, as identity markers (symbolized by a herring in the municipal flag), and by contributing to social order, cohesion and trust. The fishing fleet consisted of vessels of different sizes, which formed a stable base for the processing industry. All these have changed significantly over last decades, and there has been a steep decline both in the number of fishers ${ }^{5}$ and the amount of landed fish. Following the same pattern as the rest of the Swedish Baltic Sea, the coastal fleet in Simrishamn has been reduced from dozens of vessels in the 1960s to just a handful today, a decline that is inadequately represented in the official statistics, which do not account for differences between coastal and industrial fishing. This decline has been explained as the result of "a conjunction of technological development, disappearance of farming activities and reduced fish abundance" (Björkvik 2013, 36).

To counter this development, the municipality of Simrishamn has engaged over the last decade in various projects, forming strategic partnerships and networks with the aim of sustaining and promoting local fisheries and (re)developing the rural coastal community; a set of activities that we call the Simrishamn Initiative (henceforth SI). Between 2009 and 2013, an EU-financed Fisheries Local Action Group $\left(\right.$ FLAG) ${ }^{6}$ named South Baltic FLAG (Sydkustens Fiskeområde or SFO) played a key for establishing the SI. The purpose of SFO was to promote the long-term sustainable and diverse ecological and economic development of the fishing industry in the region (SFO 2014). One year later, the municipality established a Marine Centre ${ }^{7}$ with its headquarters in the town's harbour. The centre hosts offices of various municipal units, including one for a group of two to five experts (typically one or more biologists, a fisheries engineer and a social scientist) who were, and still are, employed to lead fisheries and other marine related projects. SFO and the Marine Centre helped to put the fisheries sector on the local political agenda, which led to pilot projects aimed at supporting the local fishery, such as Home Harbour (see Sect. 3.1), and increased political engagement in fisheries-related concerns. In 2015, Simrishamn became the first municipality in Sweden to adopt a Fishery Strategy as a policy instrument to promote local interests (Simrishamn Municipality 2015). The strategy aimed at revitalizing the

\footnotetext{
5 According to Symes and Phillipson $(2009,2)$ the decrease in number of fishers in the EU is "partly a result of modernization, economies of scale and the substitution of capital for labour, partly induced by policies to reduce fishing capacity, and also due to higher opportunity costs, improved education and increased occupational choice beyond fishing.".

${ }^{6}$ For an explanation on the context of the EU FLAGS, see https:// webgate.ec.europa.eu/fpfis/cms/farnet2/about/at-a-glance/farnet_en

${ }^{7}$ https://www.simrishamn.se/om-kommunen/marint-centrum.
} 
local market for fish, establishing and reinforcing cooperation with producer organizations ${ }^{8}$ and, over time, replacing the demand for imported fish ${ }^{9}$ with a demand for local fish. In addition, SFO and the Marine Centre were instrumental in the establishment of a medium-term cooperation partnership among municipal actors, regional actors such as the County Administrative Board of Skåne, and researchers from Lund University. These actors set up the consortium Baltic Sea Fisheries 2020 (Östersjöfiske 2020 or ÖF2020), which arranges annual conferences (planned to run from 2015 to 2020) that bring together Swedish central governmental, regional and local authorities, fishers and their representatives, and university researchers, among others, to discuss how to develop sustainable fishing on the Swedish coasts of the Baltic Sea.

\section{Community economies and the SI}

The community economies concept is derived from the Diverse Economies Research Program which emerged in the late 1980s, led by the late Julie Graham and Katherine Gibson, who writes now under the pen-name JK Gibson-Graham. Using a feminist economic analysis, this program was taken forward by an international group of scholars committed to theorizing, developing a new narrative and enacting the economy. Today, the alliance of scholars known as the Community Economy Collective (CEC) continues this agenda firstly through their "performative ontological project" or the strategy "to bring marginalized, hidden and alternative economic activities to light in order to make them more real and more credible as objects of policy and activism" (Gibson-Graham 2008, 613). As explained by Gibson-Graham and the CEC, the concept of community economies does not mean localized business activities but embodies unconventional, other definitions of both terms. Communities are defined as "the continuing outcomes of the active negotiations of interdependent forms of life; human and non-human" (Gibson-Graham et al. 2017, 5). As the authors explain, community is neither a fixed identity nor a bounded locality, but a "never-ending process of being together, of struggling over the boundaries and substance of togetherness, and of coproducing this togetherness in complex relations of power" (Gibson-Graham et al. 2017, 5). The emphasis is on the community as a process and not as a product of a collective identity and geographical locality, and the key question is whether this ongoing making of the community reflects ethical and democratic principles

\footnotetext{
${ }^{8}$ For an explanation of producer organizations see https://ec.europ a.eu/fisheries/cfp/market/producer_organisations_en

$972 \%$ of all seafood consumed in Sweden is imported mostly from Norway, Denmark and China (Borthwick et al. 2019).
}

(Gibson-Graham et al. 2017, 5). As for the term economy, it refers to "all of the practices that allow us to survive and care for each other and the earth" (Gibson-Graham et al. 2017, 5). It is for this reason that it is a mistake to talk about the economy since economies or economic practices "embrace multiple diverse, complex and contextually situated practices behind different interdependencies and motivations" (Gibson-Graham et al. 2017, 5). CEC's scholars conceive community economies as a process of explicit and democratic co-creation of various modes of acting that we collectively choose to "make our livings, receive our livings from others, and provide for others in turn" (Gibson-Graham et al. 2017, 6).

The community economy approach criticizes the focus of purely capitalist economics and stresses the need to understand, represent and perform economies differently. Gibson-Graham and the CEC expand further on the ethical concerns, or "coordinates" as they call them, upon which community economies' complex negotiations and modes of acting are built. These include: surviving together well and equitably; distributing surplus to enrich social and environmental health; encountering others in ways that support their wellbeing as well as ours; consuming sustainably; caring for (maintaining, replenishing, and growing) our natural and cultural commons; and investing our wealth in future generations so that they can live well (Gibson-Graham et al. 2017). The authors continue: "An Economy centred on these ethical considerations is what we call a community economy" and is in "the process of recognizing and negotiating, (that) we become a community" (Gibson-Graham et al. 2013, p. xix). Furthermore, a successful community economies project requires locating and bringing together a broad array of actors (human and non-human) and socio-technical devices (St. Martin et al. 2015).

Community economies can thus be understood as a conceptual approach, a process and a collective program. One important task the program sets itself is to work towards making visible and revalorizing non-capitalistic economic practices, a process described as "ontological reframing" (Gibson-Graham 2008, 620). As it is well-known, smallscale fisheries' contribution to coastal communities includes providing self- employment, supporting conditions for family-owned businesses, and acting as the source of cultural and social capital, which are difficult to reduce into monetary terms. Yet, from the perspective of community economies, these contributions are efficient economic practices, since they allow fishers' communities to survive and care for each other and the earth. These and other practices such as moonlighting, volunteer work, gifting and philanthropy, consumer organizations, etc. make up what community economy scholars define as the "diverse economies iceberg" (see Gibson-Graham 2006, 70). The iceberg is a metaphor: the mainstream view of the economy as just wage labour and 
the production of commodities for sale in capitalist markets are represented by the tip and the visible portion of the iceberg, while diverse hidden economic practices such as the ones provided by coastal fishers are located in the larger iceberg section below the water. In the process of what the same scholars name taking back the economy (see also Said and McMillan, this issue) and making other worlds possible (Roelvink et al. 2015), community economies such as the SI are performed, and the economic activities below the water are revalorized in a democratic and ethical policy-making environment.

In the following empirical section, we analyse three activities that make up the community economies project in Simrishamn. The SI's ethical commitments for the first two activities are directed to the revalorisation of (non-commodity market) contributions of coastal fisheries (see Waldo and Lovén 2019) and the calls for distributional justice regarding access to fishing rights defined in terms of principles of adjacency and historical privileges. For the third activity, the SI asserts the legitimacy of coastal fishers as stakeholders and their rights to representation in the governance system and participation in decision-making processes.

\section{Community economies in practice in Simrishamn}

We now turn to three core components of the SI: the local market project to increase the value of fish, the efforts for access to resources through regional quotas and the improvement of the representation and participation of coastal fishers in policy-making. The empirical data were partly collected for a $\mathrm{PhD}$ thesis project that explored different discourses in the Swedish Baltic Sea fisheries (Wingren, forthcoming), and partly over the course of a long-term ethnographic research project on Swedish and EU fisheries governance systems. The methods for collecting data included participant observation at meetings, conferences and workshops, and informal interviews with fishers, local politicians and municipal stakeholders between 2014 and 2019, mainly in Simrishamn. Analysis of workshops, conference reports and fisheries policy and strategy documents drawn up to support decision-making at EU, national and local levels, was also carried out over the same period.

\section{The local market project to increase the value of fish}

In the Baltic Sea, cod is a highly important fish species for environmental and commercial reasons (Harvey et al. 2003; Delaney 2007; Voss et al. 2019). Scientific stock assessments indicate that cod population has been in decline since the "golden age" of cod fishing in the 1970-80s (ICES 2018). As the state of fish stocks - and specially cod-in the
Baltic Sea worsened, it became clearer, not only to researchers, but also to coastal fishers and fisheries managers, that increasing the levels of fish exploitation was not a viable solution to support the local fisheries. Instead of increasing the volume of landings, the SI proposed to increase the value of landed fish by obtaining better prices on the local market (Tschernij 2017).

Fish landed by coastal fishers is commonly perceived by consumers as being of superior quality and freshness resulting generally in the consumer's preference for locally landed fish in comparison with industrial or aquaculture products (Schlag and Ystgaard 2013; Claret et al 2012). In Sweden as in many other places, coastal fishers depend, however, on retailers and processing companies to sell their fish which translates into the latter paying lower prices for the landed fish. Unless fish is directly sold on the quay, consumers who appreciate high quality and fresh local products are normally not informed about the origin of the fish they are buying. Nor are they informed about how the price of the fish is determined or who profits from the sale of the fish they are buying. This situation has improved in Europe since 2014 in that EU regulations require fish products to clearly state their origin by reporting for each landing the commercial and scientific name of fish, fishing gear used, catch area and net weight, production and storage conditions and "best before"/"use by date" information (EU 2013). However, no distinction is made between fish from small-scale and industrial fisheries.

To increase the economic value of fresh fish from coastal fisheries and allow them to achieve the same profits with lower landings, the SI promoted re-establishing local markets where fish could be sold directly from fishers to the consumers. A local market, they argued, would not only lead to better prices for fishers, but it would also generate more value for the region both in economic and socio-cultural terms. As one of the Marine Centre employees put it during the ÖF2020 conference in 2016:

"instead of landing fish in foreign harbours the fish would be landed locally, which would generate more employment within the region, fishers would get better prices for their fish, tax [on sales of fish] would be paid in the region, and living harbours would continue to attract people" (Tschernij 2016, authors' translation). ${ }^{10}$

To revitalize local markets, the SI launched in 2012 a pilot project called Home Harbour (hemmahamn in Swedish).

\footnotetext{
10 The SI recently repeated this argument as a response to a corruption scandal in the Swedish pelagic system that was made public in Sept. 2019. See https://www.simrishamn.se/blog/2019/09/17/vastk ustens-stora-sillfiskare-leker-gud-med-ostersjons-ekosystem
} 
Home Harbour allowed fishers to sell their fish directly to customers on Simrishamn's quay during the summer season. The Simrishamn municipality managed this project for 5 consecutive years and in 2018, two of the fishers involved took over, with quayside sales now taking place throughout the year on a regular basis. In 2019, the SI implemented a follow-up project called Fresh fish-from sea to table ${ }^{11}$ in collaboration with the Skåne Food Innovation Network and with funds from the European Maritime and Fisheries Fund through the LEADER South East Skåne project (Livsmedelsakademin 2019). During this project's kick-off meeting, a local politician described the rationale for the project as follows:

"Fish is food, not anonymous quotas. Access to fish through sustainable and fairly distributed quotas is of course a basic requirement for the fishing industry, but in order to recreate a viable fishing in the Baltic Sea, we also need to develop the market. We believe in creating value for local fishing. We can achieve this if we start to value the fish as the fine food it is, and develop access to fresh fish. We must maximize the value of the part of the fish resource we use and create a value chain that increases the profitability of the fishery. In this way, we can achieve increased value without increased extraction, which means that fishing becomes more ecologically sustainable" (Local politician from the Moderate party 2019, authors' translation).

The SI's work to develop a local market has faced a number of challenges. First, the fish landed by coastal fishers needed to be branded as a high-quality local product. In 2015, however, the eastern Baltic Sea cod lost its eco-certification from the Marine Stewardship Council (MSC) due to lack of scientific data on the population stock (MSC 2015). International NGOs such as World Wildlife Fund (WWF) have also given this cod a red light in their consumer guides, and recommend boycotting its consumption (WWF 2019). This has resulted in big supermarket chains in Sweden not purchasing Baltic Sea cod. In addition, the cod in the eastern Baltic Sea has become smaller and thinner, which has worsened its already decreased demand and price. Fishers say that in recent years they have sold their cod for no more than the price that they obtained in the 1980s, while all other costs (fuel, mooring fees, repair costs, etc.) have increased significantly. At a workshop in Simrishamn in June 2018, stakeholders from the municipality and the County Administrative Board pointed out that the Baltic cod situation is too complex for consumers, supermarkets and restaurants to make a sustainable choice on their own, so they instead

\footnotetext{
11 See https://www.smakapaskane.se/category/farsk-fisk-fran-hav-tillbord/
}

chose to follow recommendations made by NGOs. As one stakeholder expressed it: "We are in the hands of WWF. In order to keep the local fishery, we need to create a local label whose credibility is based on local (fishers) knowledge to develop new local markets" (stakeholder 2018, author's translation).

At the time of writing in 2019, the SI continues to develop local markets and brand local fish. As we have shown, their efforts are hindered from the structure and practices of existing supply chains, the condition of cod stocks, and a temporary EU ban on cod fishing in the eastern Baltic Sea since June 2019 (see Sect. 3.2). Similar initiatives in Sweden to revitalize local fish markets have been more successful, suggesting potential for wider replication. For example, the brand Öresundfisk launched by a Community Supported Fishery has been established with promising results in Malmö (west Sweden) since 2014 (Hultman et al. 2018). ${ }^{12}$

\section{Ensuring access to resources though regional quotas}

Total fisheries landings of the Swedish fleet are around 200,000 tonnes per year, of which less than $2 \%$ are landed by the coastal fleet (SWAM 2017). Landings of this coastal fleet have decreased by almost $50 \%$ in the past 20 years, from 8500 tonnes to 4500 tonnes (ibid). The poor health status of the eastern Baltic cod stock has caused the total allowable catch (TAC) for this fish to be reduced every year since 2014 until a temporary ban for cod fishing was first implemented in June 2019. However, landings of cod have been less than the TAC since 2012. According to fishers, the unprofitability of the fishery (i.e. the cost of fishing vs. the value of the fish in the market) is one of the reasons why landings have been lower than the permitted quotas. Another reason is that fishers from other regions such as the Swedish West coast, many of them larger trawlers, retain interest in fishing for eastern Baltic cod, or at least in keeping access to it through individual quotas. In comparison with coastal fishers, larger, more mobile vessels are less vulnerable to low prices for a particular fish species as they also have access to other fishing areas.

In addition to reduced TACs and finally a ban on fishing, coastal fishers have been negatively affected by the introduction of market-based regulations in Sweden in the form of Individual Transferable Quotas (ITQs). ITQs were introduced in 2009 for the management of pelagic fisheries (fish species found near the ocean surface or in middle depths, such as herring, see Bonow 2018) and in 2017 a provisional, annual ITQ system was established for demersal fisheries (fish species found on or close to the seabed) including the

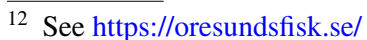


cod fishery. The aim of the ITQ system in the pelagic was to reduce the number of active fishing vessels and make the remaining ones more economically efficient (Bonow 2018; Winder 2018). ITQs are, however, considered a threat to the survival of coastal fishing communities because they lead to the concentration of quotas in a few regions in the hands of a wealthy reduced number of industrial fishers (see Hadjimichael 2018, Winder 2018, Høst 2015, Højrup 2011; Benediktsson and Karlsdottir 2011; Said and MacMillan, this issue). Moreover, ITQs for pelagic fisheries in Sweden were introduced by the Swedish Agency for Water and Marine Management (Havs- och vattenmyndigheten or $\mathrm{HaV}$ ), following a top-down process supported by the Swedish Pelagic Fisheries Producer Organization (SPFPO), which mostly represents the industrial fisheries (Gillette, unpublished data). Based on experiences of ITQ systems introduced in Denmark and Iceland, coastal fishers in Sweden perceived these market-based fisheries management changes as an additional threat to their survival.

The SI has worked to ensure a regional cod quota for the local fisheries and avoid the negative impacts of the ITQ system. In May 2018, Simrishamn municipality and the County Administrative Board of Skåne drafted a proposal to HaV demanding a regional cod quota. The document, titled Quota distribution for living Baltic Sea harbours for future generations: A proposal to guarantee the future of fisheries in our Baltic Sea harbours (authors' translation), proposes that most of the cod quota for the Baltic Sea should be allocated to a regional quota for coastal fishers who have licenses to exclusively fish cod. This proposal attracted the Swedish authorities' attention at $\mathrm{HaV}$ who decided not to introduce an ITQ system for the demersal fishery during 2019. HaV officials explained that more in-depth discussion of key issues was needed, including the social and regional goals of such a system (HaV, personal communication 2018-09-28). In the meantime, the SI's efforts to promote regional quotas have entered the public sphere through a TV documentary broadcasted nationally in April 2019 entitled "Cod - hope of the seas" (Torsken-havets hopp in Swedish), which discussed this proposal.

\section{Improving representation and participation}

As is common all along the Swedish coast, many of Simrishamn's coastal fishers are not active members of a producer organization and do not feel that their interests are well represented by the SPFPO (Gillette, unpublished data). Those who are members of a producer organization nevertheless do not necessarily have a meaningful representation in decision-making about fisheries management in the EU, whose Common Fisheries Policy (CFP) has been portrayed as one of the most centralized, top-down systems in the entire EU (Griffin 2013). In a ground-breaking reform in 2002, the EU institutionalized stakeholder participation in the CFP through the formation of so-called Advisory Councils. However, coastal fisher people and their communities have no official representation in Advisory Councils (Linke and Jentoft 2016; Griffin 2013) since they were not considered as legitimate stakeholders when the Advisory Councils were set up. Consequently, in Sweden, as in other countries, the largest national fishing associations (in Sweden producer organizations) represent all of the country's fishers, with no regard for internal diversity or conflicting interests among different sectors. This is also the case for the Baltic Sea Advisory Council, where fisheries stakeholders are represented by the most powerful industrial fisheries organizations from each member country (Linke and Jentoft 2016). As a result, decisions of crucial relevance to the small-scale sector, such as the EU-wide ban on driftnets and other fishing gear selectivity regulations, are taken without any consultation, representation or participation of stakeholders from the local level. This raises issues about democratic representation and participation in relation to environmental justice theory, as revealed for example in marine finfish aquaculture conflicts (Ertör and Ortega 2015), where demands were raised for a more even distribution of benefits and burdens, the right for stakeholder recognition and effective, transparent participation processes.

The EU's CFP has made stakeholder participation and representation problematic for the SI, both structurally and procedurally. The SI has, therefore, focused on engaging with policy and management authorities such as the County Administration Boards and the national fisheries agency $(\mathrm{HaV})$. Moreover, the $\mathrm{SI}$ is an active member of a national network of coastal municipalities that drafted and sent an open letter to the Swedish Government in 2017. The letter, often referred to as the Community Appeal (kommunupprop), was published in the national newspaper Svenska Dagbladet (SvD 2017) and highlighted how active fishing harbours and local fleets create "values such as employment and business enterprises around the fishery, as well as valuable benefits connected to local identities, trademarks and cultural heritage" (authors' translation) (SvD 2017). The letter demands that the government and national agencies should work to give local interests, in form of communities, the opportunity to influence policy and decision-making, including wider issues such as what Swedish fisheries should look like in the future and which values should be taken into account.

Despite the lack of representation and participation of local fishers at higher levels of policy- and decisionmaking, the SI has publicly raised these fishers' concerns, for example during its annual conferences or in consultation meetings organized by $\mathrm{HaV}$ or other organizations. 
Since 2017, HaV has been developing plans for an ecosystem-based approach for the Swedish fisheries that will incorporate ecological, economic and social dimensions. Furthermore, local coastal fishers' have been calling for the introduction of co-management regimes based on successful examples experienced in a handful of localities on the Swedish coast (see Bryhn et al. 2017). All these ideas are currently still under discussion at national levels of fisheries management in Sweden.

\section{The SI community economy dynamics}

\section{How did the SI emerge?}

The SI's emergence reflects the first guiding coordinate of the community economies approach (Gibson-Graham et al. 2017), the question of "what do we need to survive well?" and the answer from a specific group of people: "a local coastal fishery that thrives and maintains our local harbours alive despite its low profitability and inefficiency according to the existing capitalist logic". At the start, the SI consisted of a handful of visionaries which expanded to generate a "community of concern" (Snyder and St. Martin 2015) including local politicians from various municipalities, municipality stakeholders (actors at the Marine Centre), fishers, some partnering national and local organizations (e.g. Swedish Board of Agriculture and Skånes Food and Innovation Network), university researchers and some interested journalists from Swedish public media. Driven by the community economy guiding coordinates, this "community of concern" has engaged in actions to build an economy that reflects care and responsibility with one another (coastal fishers and coastal residents), non-human beings (cod and other fish, the harbour, the Marine Centre) and the environment (the coasts and Baltic Sea ecosystem). Different from other community economy processes, however, the SI did not arise directly from the affected coastal fishers, but rather from the municipality, which worked in continuous collaboration with the local fishers. That this community of concern began outside the individuals most deeply affected can be seen as a testimony to the key role of interdependence, ethics, and mutual care in the SI initiative. Moreover, through the process of becoming a community economy, the SI is guided nowadays towards two further of its coordinates: sustainable (fish) consumption and caring for the natural (the seas) and cultural (the coastal fishery culture) commons.

\section{How is SI maintained?}

The SI started almost ten years ago and continues to operate despite significant challenges. The initiative is driven by engaged, optimistic and creative people who work for the integration of ethical commitments based on principles of just and equitable distribution of resources, sustainable use of the seas and a fisheries management system undergirded by democratic participation. Participants in this community of concern are inspired by the evolution of the initiative in itself, but also by external dynamics, such as media campaigns that portray the large-scale fisheries sector as irresponsible, greedy and following a "business as usual" model, in comparison with a more responsible but neglected coastal fisheries sector, or even by changes in the composition of the board of directors at HaV. Crucial to the SI's success hitherto have been the opportunities to garner resources for implementing their activities with support of the municipality (as in the case of the South Baltic FLAG and LEADER projects). For example, the SI and the coastal municipalities that co-authored the letter in 2017, are currently (late 2019) applying for funding from the European Commission (channelled by the Swedish Board for Agriculture) to consolidate their network and collaborate on future coastal development and fisheries initiatives.

Although the political composition of municipality leadership has changed, the SI has continued and gained ground in its efforts to publicize the importance of coastal fisheries over the last decade. By establishing the Marine Centre and employing personnel with expert competence, the municipality served as a stable base for the SI. The knowledge, ethical commitments and engagement of the actors at the Marine Centre and close collaboration with action-research scientists from Lund University has been essential to the SI's ability to argue for their point of view in discussions at higher levels of policy and politics (e.g. with $\mathrm{HaV}$ and the Swedish Government), as well as to keep politicians informed and connected to their ongoing activities. As pointed out by Gibson et al. $(2015,216)$, local governments have crucial roles to play in supporting diverse economies and networking the initiatives that drive the community economy.

\section{How can the SI eventually spread?}

As we have noted, the SI managed to gain attention and visibility in various forums, even at the higher levels of the Swedish political milieu. For the participants in this initiative, as well as at academic levels, an important question is whether and to what extent such an isolated movement will have the potential for transformation into some broader phenomenon. Rethinking the future of Simrishamn differently, outside the dominant capitalist model, has managed to develop a resilient community of concern which seems quite well embedded at the local level after a number of years. Yet, this community economy is formally still largely 
disconnected from the national government and its agencies. Can the community economy be scaled up?

The three focus areas of the SI analysed here involve economic and ethical decisions at multiple scales. The establishment of a local market operates at the local level, the proposal to create a regional quota has a national scope, and the claim for representation and participation extends to EU levels, if coastal fishers are to be allowed to sit at the negotiation tables for legislation that affects them directly or indirectly. As Healy $(2009,341)$ argues, "a flat ontology", with no spatial categories that prearrange the world, offers initiatives such as the one in Simrishamn the potential to configure a place-based global movement for economic transformation. Because marginalized coastal fishers are present in greater or lesser numbers in most places along Swedish coasts and worldwide, the local SI could trigger a proliferation of similar initiatives and have a global scope. The political project of the diverse economy programme is to make other worlds possible (Roelvink et al. 2015) by acknowledging that there is not just one economy which is inevitably capitalistic and integrating ethical concerns in policy-making. Such a goal does not focus on the local/ global binary but instead highlights the possibility for diverse economies to "enact networks that may extend over space and include a wide variety of actors, human and nonhuman" (St. Martin et al. 2015, 20).

\section{Conclusions}

The SI experience, with its implicit aims to revalorize hidden economic activities, its ethical commitments and visions for making (an)other (Swedish rural) world possible (Roelvink et al. 2015) has evolved into a community economy itself. As such, the SI works to connect producers and consumers of fish and ensure the accessibility of coastal resources for local fishers through regional quotas based on calls for distributional justice and principles of adjacency and access to resources for diverse actors, rather than just the most economically efficient. The SI asserts the legitimacy of coastal fishers as stakeholders in fisheries and insists on their rights to representation and democratic participation in decision-making. While starting with a handful of concerned actors, the SI has over its lifetime managed to expand and develop a community of concern that has clearly brought Swedish coastal fisheries to the political arena. In addition, while there is no evidence to suggest that this community of concern shares the same principles, values or even political preferences, they clearly oppose economic growth agendas and some positive changes have started to resonate. The SI seems to be swimming upstream in a capitalocentric growthmaniacal river, yet some progress is undeniable.
As a community economies project, the SI can serve as a starting point to shift common understandings about the unequivocal benefits of a Blue Growth agenda and provoke new forms of thinking towards a Blue degrowth approach. By analysing the SI and describing its processes, we have identified crucial actors and factors that advance initiatives which seek different political and economic pathways in line with the multi-faceted Blue degrowth framework. The SI experiences, together with other similar initiatives (see e.g. Ertör-Akyazı, this issue), have thus the potential to inspire and guide initiatives for both the community economies projects and a Blue degrowth agenda. They do so by opposing an imaginary that drives less-economic efficient enterprises to extinction under a capitalist system, and claims that it will bring sustainable outcomes and wellbeing to all. All these initiatives are grounded in the idea that there are alternatives to current growth-dominated ideologies, be it in management policies, ways of harvesting or in development of markets. A similar study of resistance and alternative building in Turkish fisheries (Ertör-Akyazı, this issue) shows how such initiatives open up spaces for political contestation simultaneously as they challenge the growth imaginary and growth-driven market economy.

The SI case has revealed that despite their different disciplinary roots-feminist economics in the case of community economies and political science in the case of Blue degrowth - there are some intersections in regards to the ethical values that both approaches advocate as well as similarities at the methodological or practical levels. For example, the community economies ontological project demands a reframing of the essentialist thinking approach of the economy as exclusively capitalistic; similarly, Blue degrowth proponents advocate for the "decolonization of the imaginary," making reference to the ideological primacy of growth-based development (see Ertör and Hadjimichael, this issue) and calling for a society where the economic, social and ecological relations and imaginaries are different.

The SI, we have shown, is also about thinking differently, and in respect to fish landings, also about less. Thinking differently about less is more obvious in the SI efforts to make local markets for fresh fish, but while the actors involved do not express it this way, the SI more generally advocates for political support to an economically unprofitable sector. This requires economic decisions that oppose economic growthoriented policies (in other words, Blue degrowth) and the revalorization of non-market economies that enhance human wellbeing (in other words, community economies). However, in these first attempts to materialize Blue degrowth at a local level, degrowth is not about disregarding the importance of profits, research and innovation and the vision that we can adapt some technologies to reach sustainability. On the contrary, as our case study shows, a degrowth agenda might be recast in certain contexts into a re-politization 
project that balances between visions of communalism and eco-modernism and avoids continuing to bet for the latter when the future of the ocean is at stake.

Finally, by exploring links between community economies and Blue degrowth approaches in the Simrishamn case, we have demonstrated that degrowth should have a place in the community economies vocabulary. Given the ethical goals of the community economies theoretical framework, its capacious definition of community, and its insistence on a different understanding and anti-essentialist perspective of the economy, we find degrowth to be a resonant and productive addition to the project of identifying and enacting diverse economies.

Acknowledgements Open access funding was provided by the University of Gothenburg. The authors acknowledge gratefully Madeleine Lundin and Vesa Tschernij from the Marint Centrum at Simrishamn municipality for their always friendly and fruitful discussions with us. We also thank three anonymous reviewers for their useful comments and Maris Gillette for her valuable observations and contribution to improving the text of our manuscript. Milena Arias Schreiber and Sebastian Linke were funded by the FORMAS project "Att fiska efter lösningar: samhällsekonomi och hållbar kustutveckling i Sverige" (FORMAS grant number 2018-0025).

Open Access This article is licensed under a Creative Commons Attribution 4.0 International License, which permits use, sharing, adaptation, distribution and reproduction in any medium or format, as long as you give appropriate credit to the original author(s) and the source, provide a link to the Creative Commons licence, and indicate if changes were made. The images or other third party material in this article are included in the article's Creative Commons licence, unless indicated otherwise in a credit line to the material. If material is not included in the article's Creative Commons licence and your intended use is not permitted by statutory regulation or exceeds the permitted use, you will need to obtain permission directly from the copyright holder. To view a copy of this licence, visit http://creativecommons.org/licenses/by/4.0/.

\section{References}

Arias Schreiber M, Säwe F, Hultman J, Linke S (2017) Addressing social sustainability for small-scale fisheries in Sweden: institutional barriers for implementing the small-scale fisheries guidelines. In: Jentoft $\mathrm{S}$, Chuenpagdee R, Barragán-Paladines MJ, Franz N (eds) The small-scale fisheries guidelines: global implementation. Springer, Dordercht, pp 717-736

Arias Schreiber M, Linke S, Delaney AE, Jentoft S (2018) Governing the governance-small-scale fisheries in Europe with focus on the Baltic Sea. In: Chuenpagdee R, Jentoft S (eds) Small-scale fisheries governance: transdisciplinary analysis and practices. Springer, Dordrecht, pp 357-376

Barry J (2016) Bio-fuelling the Hummer? Transdisciplinary thoughts on techno-optimism and innovation in the transition from unsustainability. In: Byrne E, Mullally G (eds) Transdisciplinary perspectives on transitions to sustainability. Routledge, Sage, pp $106-123$

Benediktsson K, Karlsdottir A (2011) Iceland: crisis and regional development-thanks for all the fish? Eur Urban Reg Stud $18: 228-235$
Björkvik E (2013) Explaining the decline in Swedish Baltic Sea smallscale fisheries: a historical analysis of fishers in their social and ecological context. Stockholm Resilience Centre, Stockholm University, Stockholm

Bonow M (2018) Swedish fishing in the wake of ITQ. In: Winder G (ed) Fisheries, quota management and quota transfer: rationalization through bio-economics. Springer, Berlin

Boonstra W, Hentati-Sundberg J (2016) Classifying fishers' behaviour. An invitation to fishing styles. Fish Fish 17:78-100

Borthwick L, Bergman K, Ziegler F (2019) Svensk konsumtion av sjömat. Jordbruk och livsmedel RISE Rapport 2019:27

Bryhn AC, Lundström K, Johansson A, Stabo H, Svedäng H (2017) A continuous involvement of stakeholders promotes the ecosystem approach to fisheries in the 8-fjords area on the Swedish west coast. ICES J Mar Sci 74:431-442. https://doi.org/10.1093/icesj $\mathrm{ms} / \mathrm{fsw} 217$

Claret A, Guerrero L, Aguirre E, Rincón L, Hernández MD, Martínez I, Peleteiro J, Grau A, Rodríguez-Rodríguez C (2012) Consumer preferences for sea fish using conjoint analysis: exploratory study of the importance of country of origin, obtaining method, storage conditions and purchasing price. Food Qual Prefer 26:259-266

Delaney A (2007) Profiling of Small-scale fishing communities in the Baltic Sea. Study requested by the European Commission. Innovative Fisheries Management IFM. (Call FISH/2005/10)

EC (2012) Blue growth: opportunities for marine and maritime sustainable growth. Communication from the Commission to the European Parliament, the Council, the European Economic and Social Committee and the Committee of the Regions Brussels, European Commission. COM (2012) 494 final

Eikeset AM, Mazzarella AB, Davidsdottir B, Klinger DH, Levin SA, Rovenskaya E, Stenseth NC (2018) What is blue growth? The semantics of "Sustainable Development" of marine environments. Mar Policy 87:177-179

Eliasen SQ, Hegland TJ, Raakjær J (2015) Decentralising: the implementation of regionalisation and co-management under the post2013 Common Fisheries Policy. Mar Policy 62:224-232

Ertör I, Cerdà M (2015) Political lessons from early warnings: marine finfish aquaculture conflicts in Europe. Mar Policy 51:202-210

EU (2013) Regulation (EU) No 1379/2013 of the European Parliament and of the Council of 11 December 2013 on the common organisation of the markets in fishery and aquaculture products, amending Council Regulations (EC) No 1184/2006 and (EC) No 1224/2009 and repealing Council Regulation (EC) No 104/2000

Gascuel D, Coll M, Fox C et al (2016) Fishing impact and environmental status in European seas: a diagnosis from stock assessments and ecosystem indicators. Fish Fish 17:31-55

Gibson-Graham JK (2006) Postcapitalist politics. University of Minnesota Press, Minneapolis

Gibson-Graham JK (2008) Diverse economies: performative practices for 'other worlds'. Prog Hum Geogr 32:613-632

Gibson-Graham JK, Cameron J, Healy S (2013) Take back the economy: an ethical guide for transforming our communities. University of Minnesota Press, Minneapolis

Gibson K, Cahill A, McKay D (2015) Diverse economies, ecologies, and ethics: rethinking rural transformation in the Philippines. In: Roelvink G, St Martin K, Gibson-Graham JK (eds) Making other worlds possible: performing diverse economies. University of Minnesota Press, Minneapolis, pp 194-224

Gibson-Graham JK, Cameron J, Dombrowski K, Healy S, Miller E (2017) Cultivating community economies, tools for building a liveable world-The Next System Project. https://thenextsystem. org/cultivating-community-economies/

Griffin L (2013) Good governance, scale and power a case study of North Sea fisheries. Routledge, New York

Gustavsson T (2018). Community profile Simrishamn-sub-contracted study within the project. Profiling of small-scale fishing 
communities in the Baltic Sea. In: Delaney A (ed) Profiling of Small-scale fishing communities in the Baltic Sea. Study requested by the European Commission. Innovative Fisheries Management IFM. (Call FISH/2005/10), pp 43-64

Hadjimichael M (2018) A call for a blue degrowth: unravelling the European Union's fisheries and maritime policies. Mar Policy. https://doi.org/10.1016/j.marpol.2018.05.007

Harvey CJ, Cox SP, Essington TE, Hansson S, Kitchell JF (2003) An ecosystem model of food web and fisheries interactions in the Baltic Sea. ICES J Mar Sci 60:939-950. https://doi.org/10.1016/ S1054-3139(03)00098-5

Healy S (2009) Economies, Alternative. In: Kitchin R, Thrift N (eds) The international encyclopedia of human geography, vol 3. Elsevier, Oxford, pp 338-344

Højrup T (2011) The need for common goods for coastal communities: common community quotas for sustainable life-modes in coastal fisheries: the common fisheries policy has to recognize: the alternative to privatization of fishing rights in the home waters of Europe. Narayana, Gylling

Høst J (2015) Market-based fisheries management-private fish and captains of finance. Springer. https://stud.epsilon.slu.se/8834/1/ krogseng_k_160218.pdf

Hultman J, Säwe F, Salmi P, Manniche J, Bæk Holland E, Høst J (2018) Nordic fisheries at a crossroad. TemaNord 2018:546. http://norde n.diva-portal.org/smash/get/diva2:1253218/FULLTEXT01.pdf

ICES (2018) Cod (Gadus morhua) in subdivisions 22-24, western Baltic stock (western Baltic Sea). 10.17895/ices.pub.4377

Jentoft S (2019) Life above water-essays on human experiences of small-scale fisheries. TBTI Global Book Series 1

Kallis G, Demaria F, D'alisa G (2014) Introduction: degrowth. In: D'alisa G, Demaria F, Kallis G (eds) Degrowth: a vocabulary for a new era. Routledge, London

Krogseng K (2016) The decline of small-scale fisheries: a case study in Blekinge. Master Thesis Swedish University of Agricultural Sciences

Linke S, Jentoft S (2016) Ideals, realities and paradoxes of stakeholder participation in EU fisheries governance. Environ Sociol $2: 144-154$

Livsmedelsakademin (2019) Om färsk fisk -från hav till bord." Retreived 2019-09-15, from https://www.smakapaskane.se/categ ory/farsk-fisk-fran-hav-till-bord/

Lloret J, Cowx IG, Cabral H, Castro M, Font T, Gonçalves JMS, Gordoa A, Hoefnagel E, Matić-Skoko S, Mikkelsen E, Morales-Nin B, Moutopoulos DK et al (2018) Small-scale coastal fisheries in European Seas are not what they were: Ecological, social and economic changes. Mar Policy. https://doi.org/10.1016/j.marpo 1.2016.11.007

Menzies CR (2011) Red flags and lace coiffes: Identity and survival in a Breton village. University of Toronto Press, Toronto

MSC (2015) MSC certificates for Eastern Baltic Sea cod fisheries suspended. Retrieved 25-02-2019, from https://www.msc.org/media -centre/press-releases/msc-certificates-for-eastern-baltic-sea-codfisheries-suspended

Prellezo R, Accadia P, Andersen JL, Andersen BS, Buisman E, Little A, Nielsen JR, Poos JJ, Powell J, Röckmann C (2012) A review of EU bio-economic models for fisheries: the value of a diversity of models. Mar Policy 36:423-431

Roelvink G, St Martin K, Gibson-Graham JK (eds) (2015) Making other worlds possible: performing diverse economies. University of Minnesota Press, Minneapolis
Said A, Tzanopoulos J, MacMillan D (2016) Bluefin tuna fishery policy in Malta: the plight of artisanal fishermen caught in the capitalist net. Mar Policy 73:27-34

Schlag K, Ystgaard K (2013) Europeans and aquaculture: perceived differences between wild and farmed fish. Br Food J 115:209-222. https://doi.org/10.1108/00070701311302195

Schneider F, Kallis G, Alier J (2010) Crisis or opportunity? Economic degrowth for social equity and ecological sustainability. J Clean Prod 18:511-518

Scientific, Technical and Economic Committee for Fisheries (STECF) (2018) The 2018 Annual Economic Report on the EU Fishing Fleet (STECF-18-07). Publications Office of the European Union, Luxembourg. 10.2760/56158

SFO (2014). Sydkustens fiskeområde. Mellanrapport 2014-02-28. Simrishamn.

Simrishamn (2015) Policy för bevarande och utveckling av fiskerinäringen i Simrishamn. Antagen av kommunfullmäktige 2015-08-31, Simrishamn kommun

Simrishamn Municipality (2019) "Om kommunen". https://www.simri shamn.se/om-kommunen/.

Snyder R, St. Martin K (2015) A fishery for the future: the Midcoast Fishermen's Association and the work of being-in-common. In: Roelvink G, St. Martin K, Gibson-Graham JK (eds) Making other worlds possible: performing diverse economies. University of Minnesota Press, Minneapolis

St. Martin K, Roelvink G, Gibson-Graham JK (2015) Introduction: an economic politics for our time. In: Roelvink G, St. Martin K, Gibson-Graham JK (eds) Making other worlds possible: performing diverse economies. University of Minnesota Press, Minneapolis

SvD (2017) Det lokala fisket riskerar att försvinna helt. Svenska Dagbladet 29 Juni 2017. https://www.svd.se/det-lokala-fisket-riske rar-forsvinna-helt

SWAM (2017) Havs och vatten myndigheten. SwAM's statistical database of catches. https://havbi.havochbatten.se, https://havbi.havoc hvatten.se/analytics/saw.dll?PortalPages

Symes D, Phillipson J (2009) Whatever became of social objectives in fisheries policy? Fish Res 95:1-5

Tschernij V (2016) Bevara det lokala fisket. Presentation at: ÖF2020 konferens 11 Nov. 2016

Tschernij V (2017) Kan hållbar konsumtion vara lösningen till hållbara bestånd? Presentation at ÖF2020 conference 2017. Simrishamn

Voss R, Quaas MF, Stiasny MH, Hänsel M, Pinto GA, Lehmann A, Reusch TBH, Schmidt JO (2019) Ecological-economic sustainability of the Baltic cod fisheries under ocean warming and acidification. J Environ Manage 238:110-118

Waldo S, Lovén I (2019) Värden i svenskt yrkesfiske, Agrifoods Economics Centre. RAPPORT 2019:1

Winder G (ed) (2018) Fisheries, quota management and quota transfer: rationalization through bio-economics. Springer, Berlin

Wingren I (forthcoming) Framing and scaling the crisis in Swedish Baltic Sea fisheries. PhD thesis, defense planned in 2020. Lund University, Lund

WWF (2019) Torsk. https://fiskguiden.wwf.se/blog/fiskar/torsk/

Publisher's Note Springer Nature remains neutral with regard to jurisdictional claims in published maps and institutional affiliations. 